\title{
Absolute Isotopic Abundance Ratios and the Atomic Weight of a Reference Sample of Potassium
}

\author{
E. L. Garner, T. J. Murphy, J. W. Gramlich, \\ P. J. Paulsen, and I. L. Barnes \\ Institute for Materials Research, National Bureau of Standards, Washington, D.C. 20234
}

(August 27, 1975)

\begin{abstract}
Solid sample, thermal ionization, mass spectrometry has been used to obtain absolute values for the isotopic abundance ratios of a reference sample of potassium. Standards of known isotopic composition, prepared by gravimetrically mixing nearly isotopically and chemically pure separated isotopes of ${ }^{39} \mathrm{~K}$ and ${ }^{41} \mathrm{~K}$, were used for calibration. The absolute isotopic abundance ratios are ${ }^{39} \mathrm{~K} /{ }^{41} \mathrm{~K}=13.8566 \pm$ 0.0063 and ${ }^{40} \mathrm{~K} /{ }^{41} \mathrm{~K}=0.0017343 \pm 0.0000061$ which yield atom percent compositions of ${ }^{39} \mathrm{~K}=93.2581 \pm$ $0.0029 .{ }^{40} \mathrm{~K}=0.01167 \pm 0.00004$. and ${ }^{41} \mathrm{~K}=6.7302 \pm 0.0029$. The calculated atomic weight for pot assium is $39.098304 \pm 0.000058$. The indicated uncertainties are overall limits of error which are the sum of the uncertainty components for ratio determinations and the components covering the effects of known sources of possible systematic error.
\end{abstract}

Key words: Absolute ratios; atomic weight; isotopic abundance; potassium; reference standard.

\section{Introduction}

The Analytical Spectrometry Section of the National Bureau of Standards is conducting a long term program of absolute isotopic abundance ratio and atomic weight determinations using the mass spectrometric method. Previous atomic weight determinations include silver [1], ${ }^{1}$ chlorine [2], copper [3], bromine [4], chromium [5], magnesium [6], lead [7], boron [8], rubidium [9], rhenium [10], and silicon [11]. The present work extends the study to potassium.

A mass spectrometric determination of the atomic weight of an element requires a determination of the absolute isotopic abundance of a reference standard and also the establishment of limits for natural variations. The essential criteria for obtaining absolute isotopic abundances from relative or observed isotopic ratios is calibration of the instrument for the effects of bias using calibration standards of the analyte element with accurately known isotopic ratios. Accurately known calibration standards are prepared by gravimetrically mixing nearly isotopically and chemically pure separated isotopes of the analyte element. The uncertainty in the absolute ratio of the reference standard due to the assay and mixing of the separated isotopes must be within \pm 0.02 percent to obtain the desired high accuracy atomic weight results. Mass spectrometric analysis of the reference standard and the calibration standard under nearly , tentical analyti-

'Figures in brackets indicate the literature references at the end of this paper. cal conditions provides the means of calculating correction factors (calculated isotopic ratio of calibration standard/observed isotopic ratio of calibration standard) which when applied to the observed ratios of the reference standard being calibrated yield absolute isotopic abundance ratios for the standard. The atomic weight of the reference standard can then be calculated from the absolute abundances and the nuclidic masses reported by Wapstra and Gove [12]. Establishing the limits of natural variability requires a sampling of minerals from different geographic and geological origins on a world-wide basis. The uncertainty components due to possible natural variations, the ratio determination and other known sources of possible systematic error are summed to obtain an overall limit of error for the atomic weight of the element. A more detailed discussion of the mass spectrometric determination of the atomic weights of the elements is given by Cameron [13].

Naturally occurring potassium consists of stable isotopes ${ }^{39} \mathrm{~K}$ and ${ }^{41} \mathrm{~K}$, and a radioactive isotope ${ }^{40} \mathrm{~K}$. With a half-life of approximately $1.4 \times 10^{9}$ years, ${ }^{40} \mathrm{~K}$ is changing by beta emission to ${ }^{40} \mathrm{Ca}$ and by orbital electron capture to ${ }^{40} \mathrm{Ar}$. Since the stable isotopes are 99.988 percent of the total number of potassium atoms present, the effect of the total amount of ${ }^{40} \mathrm{~K}$ on the atomic weight is only 2.6 parts-per-million. During the course of a $10^{9}$ year half-life the decay of ${ }^{40} \mathrm{~K}$ will decrease the atomic weight by 1.5 parts-per-million (ppm).

Prior to 1951 the International Commission on 
Atomic Weights used data from the chemical combining weight method as the source for establishing the potassium atomic weight. All of the mass spectrometric isotopic abundance data available at that time were relative measurements, which could not be corrected for bias effects because of insufficient information. Secondly, there were conflicting reports which indicated both large natural variations $[14,15,16,17$, $18,19,20,21]$, and a high degree of constancy $[22$, $23]$ in the isotopic abundances of potassium. These two factors weighed heavily against the use of mass spectrometric data as a source of information for the atomic weight of potassium.

In what was considered a benchmark in analytical mass spectrometry at the time of the measurement in 1950, Nier [24] calibrated for the effects of bias with standards of known isotopic composition prepared from high purity separated isotopes of argon. Reuterswärd [25], in an extensive effort to identify and correct for bias in the mass spectrometric measurement, discussed the risk of accepting a calibration which did not use potassium separated isotopes. Although extensive in scope, the calibration of Reuterswärd did not include calibration with standards of known isotopic composition. The atomic weight calculated from his abundance data was 39.101 and did not provoke any serious misgivings about the 1951 report of the International Commission on Atomic Weights [26] which accepted the 1950 isotopic abundance measurements of Nier as the basis for calculating the atomic weight of potassium.

Since 1951, the values recommended for the atomic weight of potassium by the International Commission on Atomic Weights have fluctuated between 39.098, obtained from the chemical method, and 39.102, obtained from the mass spectrometric method. Much of the indecision was due to an apparent difference of 0.01 percent between the methods and the lack of new sources of data or a high accuracy measurement to resolve the discrepancy. Tables 1 and 2 give a detailed summary of atomic weight $\left({ }^{12} \mathrm{C}=12\right)$ data by these methods. The mass spectrometric data is not inclusive of all published isotopic data but is representative of the measurements published since 1930. Where investigators reported natural variations, the ${ }^{39} \mathrm{~K} /{ }^{41} \mathrm{~K}$ value for the standard or mineral most representative of terrestrial potassium was used for the atomic weight calculation. Examining the data from a point of view that none of the measurements satisfy the criteria for an absolute abundance determination, the average and range obtained is similar to the chemical data. The new source of information which eventually produced the revision to $39.098 \pm 0.003$ as the accepted value by the International Commission on Atomic Weights was Marinenko's [36] discussion of the data of Bates and Wichers [37], obtained from potentiometric titration of acids.

The primary purpose of the research reported here was a high accuracy determination of the atomic weight of potassiam which would resolve the apparent discrepancy between the chemical and mass spectrometric data. To accomplish this goal, six calibration standards of known isotopic composition were prepared by gravimetrically blending isotopically and chemically pure separated isotopes of ${ }^{39} \mathrm{~K}$ and ${ }^{41} \mathrm{~K}$. A secondary purpose was to provide an isotopic standard of accurately known composition which can serve as a stabilizer in geochemistry where the search for potassium variations has produced a collection of diverse and conflicting relative isotopic measurements. The material chosen for the isotopic standard was a potassium chloride (Standard Reference Material 985) obtained from the J. T. Baker Chemical Company², Phillipsburg, New Jersey.

${ }^{2}$ Company names are identified in this paper. Such identification does not imply recom mendation or endorsement by the National Bureau of Standards.

\begin{tabular}{|c|c|c|c|c|}
\hline Year & Investigator & & Aethod & Atomic \\
\hline \multirow[t]{2}{*}{1906} & \multirow[t]{2}{*}{ Richards and Staehler [27] } & $\frac{\mathrm{KCl}}{\mathrm{A} g}$ & $=0.691072$ & 39.092 \\
\hline & & $\frac{\mathrm{KCl}}{\mathrm{AgCl}}$ & $=0.0520118$ & 39.091 \\
\hline \multirow[t]{2}{*}{1907} & \multirow[t]{2}{*}{ Richaris and Müeller [28] } & $\frac{\mathrm{KCl}}{\mathrm{A}_{\square}}$ & $=0.69107$ & 39.091 \\
\hline & & $\frac{\mathrm{KCl}}{\mathrm{A} \oplus \mathrm{Cl}}$ & $=0.52012$ & 39.091 \\
\hline \multirow[t]{2}{*}{1928} & \multirow[t]{2}{*}{ Ḧ̈nigschmid and Gaubeau [29] } & $\frac{\mathrm{KBr}}{\mathrm{A}_{\square}}$ & $=1.103270$ & 39.104 \\
\hline & & $\frac{\mathrm{KBr}}{\mathrm{AgCl}}$ & $=0.63374$ & 39.101 \\
\hline
\end{tabular}


TABLE 1. Recalculation of atomic weight of potassium $\left({ }^{12} \mathrm{C}=12\right)$-Continued

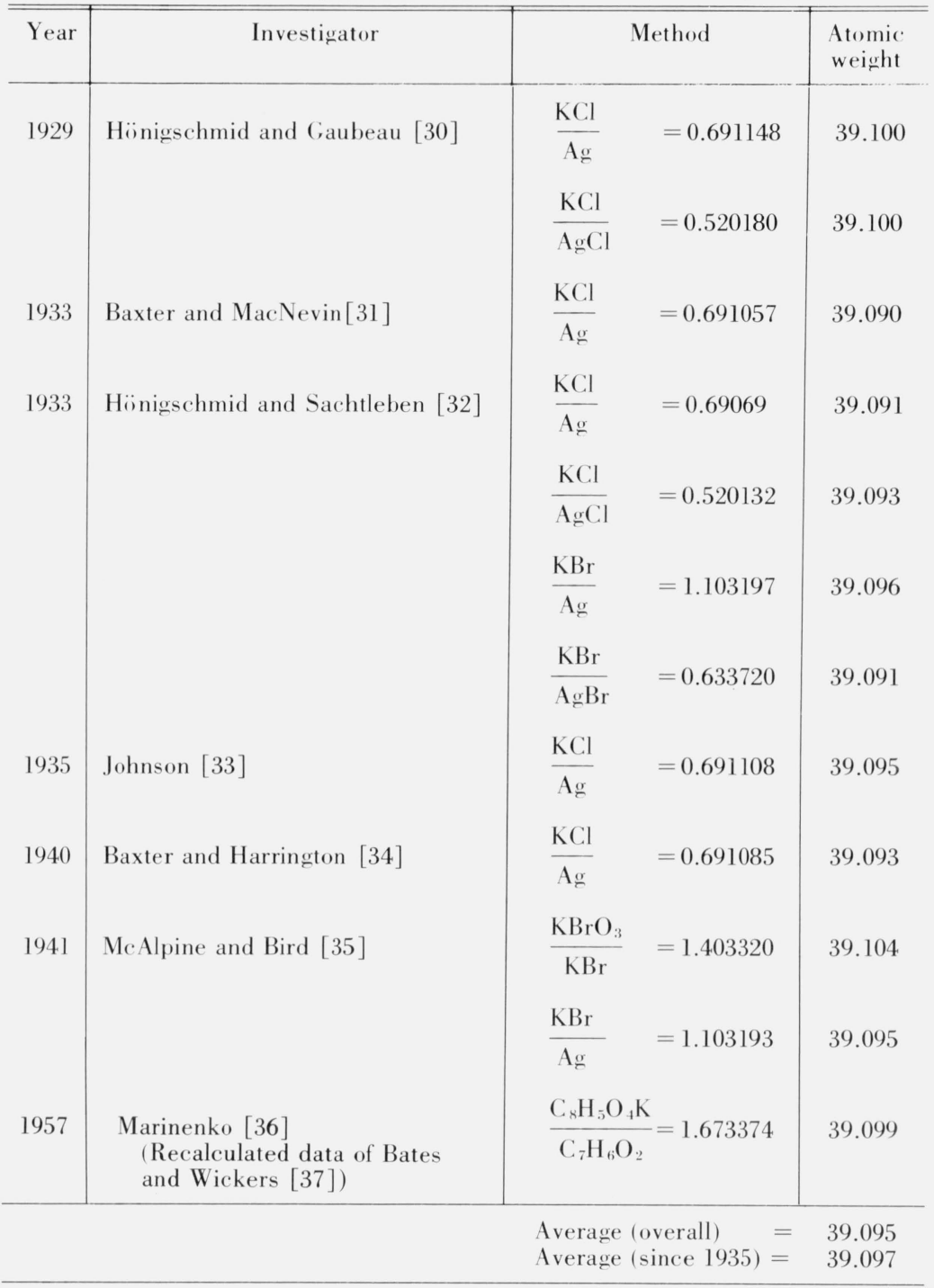

TABLE 2. Calculation of atomic weight of potassium from relative mass spectrometric measurements

\begin{tabular}{l|l|c|c}
\hline \hline Year & \multicolumn{1}{|c|}{ Investigator } & ${ }^{39} \mathrm{~K} /{ }^{41} \mathrm{~K}$ & $\begin{array}{c}\text { Atomic weight } \\
(12 \mathrm{C}=12)\end{array}$ \\
\hline 1934 & Brewer and Kueck [38] & $13.88 \pm 0.4$ & 39.098 \\
1935 & Nier [39] & $13.96 \pm 0.1$ & 39.097 \\
1936 & Manley [40] & $13.4 \pm 0.5$ & 39.102 \\
1936 & Bondy and Vanicek [41] & $14.1 \pm 0.1$ & 39.096 \\
1943 & Cook [22] & $14.12 \pm 0.28$ & 39.096 \\
1944 & Paul [42] & $13.66 \pm 0.6$ & 39.097 \\
1948 & White and Cameron [43] & $13.81 \pm 0.15$ & 39.100 \\
1948 & Hibbs and Redmond [44] & $13.48 \pm 0.07$ & 39.099 \\
1950 & Nier [24] & $13.32 \pm 0.04$ & 39.102 \\
1951 & Reuterswärd [45] & $13.79 \pm 0.09$ & 39.094 \\
1956 & Reuterswärd [25] & $13.96 \pm 0.05$ & 39.101 \\
1956 & White et al. [46] & $13.769 \pm 0.029$ & 39.099 \\
1958 & Omura and Morito [47] & $14.33 \pm 0.06$ & 39.097 \\
1960 & Kendall [23] & & 39.099 \\
1962 & Harms et al. [15] &
\end{tabular}


TABLE 2. Calculation of atomic weight of potassium from relative mass spectrometric measurements - Continued

\begin{tabular}{c|l|c|c}
\hline Year & \multicolumn{1}{|c|}{ Investigator } & ${ }^{39} \mathrm{~K} /{ }^{41} \mathrm{~K}$ & $\begin{array}{c}\text { Atomic weight } \\
\left({ }^{2 \cdot 2} \mathrm{C}=12\right)\end{array}$ \\
\hline 1962 & Letolle [16] & $13.85 \pm 0.06$ & 39.098 \\
1962 & Stauffer and Honda [48] & $14.23 \pm 0.01$ & 39.095 \\
1963 & Shukolyukov et al. [49] & $13.96 \pm 0.09$ & 39.097 \\
1965 & Schreiner and Verbeek [50] & $14.19 \pm 0.01$ & 39.095 \\
1973 & Barnes et al. [51] & $14.015 \pm 0.014$ & 39.097 \\
\hline \multicolumn{2}{c}{ Average 39.098 } \\
\hline
\end{tabular}

a Calculated with a ${ }^{40} \mathrm{~K} /{ }^{41} \mathrm{~K}$ value of 0.0017343 for all investigators.

\section{Experimental Procedure}

\subsection{Mass Spectrometry}

Isotopic abundance ratios of the reference standard (Standard Reference Material 985), calibration mixes and separated isotopes were determined by solid sample, thermal ionization mass spectrometry. Two single stage, solid sample mass spectrometers (a $15 \mathrm{~cm}$ radius of curvature, $60^{\circ}$ analyzer tube instrument and a $30 \mathrm{~cm}$ radius of curvature, $90^{\circ}$ analyzer tube instrument) were used to obtain two independent sets of isotopic ratio measurements. Both mass spectrometers were equipped with interchangeable and nearly identical electronic components, identical thin lens "Z" focusing ion sources [52], and the same basic design of a multielement, deep-bucket faraday cage collector $[52,53,54]$.

The collectors, especially designed for in-depth suppression of secondary electrons, were equipped with a tungsten ribbon $(0.025 \times 0.76 \mathrm{~mm})$ transmission grid shadowing a series of $0.10 \mathrm{~mm}$ suppressor grids. The other components for each measuring circuit were a pair of vibrating reed electrometers, an expanded-scale strip-chart recorder, a voltage to frequency converter and a scaler-timer. Data acquisition was computer controlled with the $15 \mathrm{~cm}$ instrument interfaced to a central, time-shared computer and the $30 \mathrm{~cm}$ instrument interfaced to its own minicomputer. Under computer controlled operation, all phases of the ratio measurement and data reduction were programed and automatic with the exception of ranging of the vibrating reed electrometers. This was accomplished manually by programing a magnet switching delay at the end of each peak top observation which was of sufficient duration to permit manual ranging. Operators retained at all times the options for digital, expanded scale recorder or simultaneous digital-recorder measurements.

Absolute isotopic abundance studies of uranium [54] established that the basic expanded-scale measuring circuit, including the multielement faraday cage - Ilector, is linear over a ratio range $20: 1$ to $1: 20$. It was also established that for this range of isotopic ratios, a single mass dependent correction factor could be experimentally determined and applied to correct for bias effects. Corroborative support for this is provided by previous work in the atomic weight program where the isotopic ratios of a wide range of synthetic calibration mixes of the elements boron [8], chromium [5], magnesium [6], rubidium [9], and rhenium [10], were measured and compared to known values. Since most of the absolute isotopic abundance data obtained at NBS was with the expanded scale recorder, a considerable effort was made to prove the linearity of the digital measuring circuit. This was accomplished by a comparison of the digital and expanded scale recorder data obtained under simultaneous measurement conditions. Linearity of the digital circuits used in this experiment were found to be $\leqslant 0.02$ percent.

Potassium was thermally ionized from a tantalum triple filament $(0.025 \times 0.76 \mathrm{~mm})$ source. This filament material was selected in preference to other materials because of its poor ionization efficiency for calcium and the relative ease of reducing the potassium background ion current of a tantalum filament to $1 \times 10^{-15} \mathrm{~A}$. Prior to filament fabrication, the tantalum ribbons were boiled in ultra-high-purity water to remove all water soluble surface contaminants, rinsed in a second wash of ultra-high-purity water, and dried with a heat lamp in a clean air environment. After fabrication, the filaments were degassed in a vacuum and under a potential field. All filaments were degassed for $1 \mathrm{~h}$ at $4 \mathrm{~A}$ and then at an increased current of $4 \frac{1}{2} \mathrm{~A}$ for one-half hour. After minimum cooling of $30 \mathrm{~min}$, the final cleaning was accomplished by a flashing procedure. This procedure consisted of a series of 1-min cycles in which the filaments were alternately pulsed with a 4 A current and then cooled for periods of 5 to $15 \mathrm{~s}$. Bare filaments cleaned in this manner exhibited a potassium background ion current of $\leqslant 1 \times 10^{-15} \mathrm{~A}$.

An evaluation of borosilicate glass, polyethylene, quartz, and Teflon containers over a 3-month period resulted in the selection of Teflon $\mathrm{FEP}^{3}$ as the most acceptable for long-term storage of potassium solutions. Polyethylene containers were the least acceptable because of the relatively large amounts of material leached from some of the containers after stringent cleaning. Microgram amounts of organic or inorganic impurities on the sample filaments with $10-15 \mu \mathrm{g}$ of potassium, changed the isotopic fractionation pattern of a high purity potassium chloride standard from a significantly decreasing ${ }^{39} \mathrm{~K} /{ }^{4} \mathrm{~K}$ ratio to a nearly con${ }^{3}$ A commercial material is identified in this paper in order to adequately specify experi-
mental procedure. Such identification does not imply recommendation or endorsement by the National Bureau of Standards. 
stant or increasing ratio with time [55]. Thus, a "dirty" standard, independent of the source of the impurities, showed a bias when compared to the same high purity standard analyzed under identical conditions. The deleterious effects of impurities on the accuracy of potassium isotopic measurements is well documented $[22,23,25,50,55,56]$. The Teflon FEP containers were cleaned for a prolonged period of 1 week in hot, ultra-high purity $(1+1)$ nitric acid [57], rinsed with ultra-high purity water, leached for 1 week in hot, ultra-high purity $(1+1)$ hydrochloric acid, rinsed with ultra-high purity water and dried in a Class 100 clean air environment. The containers were then filled with ultra-high purity $(1+1)$ hydrochloric acid, capped and stored in a clean air environment until needed. Prior to adding potassium solutions, the containers were thoroughly rinsed with ultra-high purity water.

Quartz tubing was used to make the pipets which were used to transfer solution from sample storage containers to the filaments. The quartz tubing was cleaned by heating in nitric acid $(1+1)$ for $48 \mathrm{~h}$, rinsed several times in warm high purity water, boiled in ultra-high purity nitric acid $(1+1)$, rinsed in warm ultra-high purity water, and dried in a clean air environment by heat lamps. Immediately before trans. ferring solution for analysis, additional cleaning was accomplished by flushing with high purity hydrochloric acid $(1+49)$, rinsing with ultra-high purity water, and conditioning with an expendable aliquot of the sample to be analyzed. The effects of environmental contamination on cleaned filaments and pipets were minimized by careful handling and storage in a Class 100 clean air environment.

Potassium was deposited on the sample filaments as dilute hydrochloric acid solutions $(1+49)$ of potassium chloride at a concentration of $2.5 \mathrm{mg}$ of potassium per $\mathrm{ml}$. One drop, $5 \mu \mathrm{l}$ for MS \# 1 and $10 \mu \mathrm{l}$ for MS \#5, were evaporated to dryness on each sample filament with heat lamps and electrical currents which were adjusted as follows: $1.0 \mathrm{~A}$ for $10 \mathrm{~min}$ : $1.2 \mathrm{~A}$ for $5 \mathrm{~min}$ : and $1.5 \mathrm{~A}$ for $5 \mathrm{~min}$. The heat lamps and electrical currents were turned off and the filaments allowed to cool $5 \mathrm{~min}$ before removal from the clean air environment. Sample filament alinement and spacing criteria required positioning these filaments the maximum distance of approximately $0.5 \mathrm{~mm}$ from the edges of the ionizing filament. This type of open spacing was used to reduce the effects of radiant heat by the ionizing filament.

Potassium ions were measured at a constant accelerating voltage of $3.8 \mathrm{kV}$ by varying the magnetic field via a temperature compensated. Hall effect controller. For the mass spectrometric analysis, the ionizing filament was maintained at $1250{ }^{\circ} \mathrm{C}$ (direct pyrometer reading) and the sample filament currents were initially adjusted to $0.6 \mathrm{~A}$. At specified times of 5 and 10 min into the analysis, the $\mathrm{K}^{+}$ion current was adjusted to $5 \times 10^{-11} \mathrm{~A}$ and $1.0 \times 10^{-10} \mathrm{~A}$, respectively. No further adjustments were made until the ion current exhibited a growth pattern. Failure to produce an ion current growth pattern within $25 \mathrm{~min}$ after starting the run was sufficient cause for termination and rejection of the analysis. Under ion current growth conditions, the sample filament currents were adjusted to yield intensities of $1.5 \times 10^{-10} \mathrm{~A}$ and $2.0 \times 10^{-10} \mathrm{~A}$ at specified times of 15 and 20 min into the analysis. No further adjustments were normally required. The ratio measurement which was started after $40 \mathrm{~min}$ of heating was made in the sequence of ${ }^{39} \mathrm{~K} /{ }^{41} \mathrm{~K},{ }^{41} \mathrm{~K} /{ }^{40} \mathrm{~K}$. ${ }^{39} \mathrm{~K} /{ }^{41} \mathrm{~K}$. While the two operators did not select or use the same parameters, such as sample size, sample mounting, heating pattern, and signal intensity, rigid standardization was maintained on each mass spectrometer. Isotopic fractionation was observed and, under normal conditions, the ${ }^{39} \mathrm{~K} /{ }^{41} \mathrm{~K}$ decreased $\leqslant 0.2$ percent during the $45 \mathrm{~min}$ ratio measuring period. The effects of secondary electrons were observed in the vicinity of the ${ }^{40} \mathrm{~K}$ base and were due primarily to the $10^{-10} \mathrm{~A}{ }^{39} \mathrm{~K}$ ion current. Reducing the $x$-axis opening into the collector with a baffle removed the large ${ }^{39} \mathrm{~K}$ ion beam from the collector plates when the ${ }^{4 \prime} \mathrm{K}$ ion beam was focused on the faraday cage. This procedure was successfully used on both instruments to minimize the effects of secondary electrons. How ever, as collector plates were coated with a thin layer of potassium, suppression of secondary electrons became uncontrollable. It was necessary to remove the collector, thoroughly clean all surfaces and replace the tungsten transmission grids with virgin ribbon. This cleaning procedure was necessary and essential after approximately 50 analyses. Efforts to clean the tungsten transmission grids were unsuccessful and, under such conditions, deterioration of secondary electron suppression was rapid and unacceptable within 20 analyses. Contributions from the ${ }^{39} \mathrm{~K}$ tail at the ${ }^{40} \mathrm{~K}$ mass position were not detectable on the $30 \mathrm{~cm}$ instrument but were $\leqslant 1 \times 10^{-15} \mathrm{~A}$ on the $15 \mathrm{~cm}$ instrument. This tailing effect limited the accuracy of ${ }^{40} \mathrm{~K} /{ }^{41} \mathrm{~K}$ measurements with the digital system.

Although memory was not detected when the ${ }^{39} \mathrm{~K}$ and ${ }^{41} \mathrm{~K}$ separated isotopes were analyzed in an alternate pattern on the same source, or when analyzed in a similar pattern with natural or isotope dilution samples, it was known that significant amounts of potassium were deposited on the ion source during an analysis. Since $K$ ions contributed from residual potassium can be a source of significant error, the ion source was removed from the mass spectrometer, disassembled, and thoroughly cleaned before analysis of each separated isotope, the equal atom calibration mix, and the reference standard and remainin $y$ calibration mixes. All tools and associated sample mounting apparatus were also cleaned with each source cleaning. The clean ion source was first degassed for at least $1 \mathrm{~h}$ with a bare set of filaments and then conditioned for $90 \mathrm{~min}$ with a sample of the approximately isotopic abundance to be analyzed.

\subsection{Purification of the Separated Isotopes}

Electromagnetically separated ${ }^{39} \mathrm{~K}$ and ${ }^{41} \mathrm{~K}$ isotopes in the form of potassium chloride were obtained from the Isotopes Division, Oak Ridge National Laboratory 
of the Union Carbide Nuclear Company. The ${ }^{39} \mathrm{KCl}$ and the ${ }^{41} \mathrm{KCl}$ were designated series 107401 and 149401, respectively. The certificates of analysis which accompanied each sample included a semiquantitative spectrographic analysis which showed that zinc could be present at the 0.2 percent level and several other elements, including aluminum, cadmium, cobalt, chromium, and nickel could be present up to the 0.5 percent level. To reduce these impurities to a level low enough so that they could not cause a significant error in the determination of the potassium, the separated isotope samples were further purified. The purification method used which was based on the crystallization of potassium perchlorate had been previously found by this laboratory to be effective for removing cationic and anionic impurities from rubidium chloride with the exception of potassium and cesium which cocrystallized with the rubidium [9]. The effectiveness of this purification procedure for potassium, in which potassium perchlorate is crystallized, was first tested by the purification of natural potassium chloride to which $1,000 \mathrm{ppm}$ of 21 common elemental impurities had been added. The results of the analysis of the purified material by spark source-isotope dilution analysis is shown in table 3 . Only sodium and iron were detected at the 10-ppm level and most of the other elements were at the low ppm level. The purification method does not separate rubidium or cesium.

Each separated isotope sample was purified as follows: The potassium chloride (about $3.5 \mathrm{~g}$ ) was dissolved in $50 \mathrm{ml}$ of $0.02 \mathrm{~N} \mathrm{HCl}$ in a Teflon-FEP beaker. The solution was filtered through a close textured filter paper that had been previously washed with $200 \mathrm{ml}$ of $5 \mathrm{~N} \mathrm{HCl}$ into a Teflon-FEP beaker. The filtrate was diluted to $100 \mathrm{ml}$, and $6 \mathrm{ml}$ of high-purity perchloric acid were added. The precipitated $\mathrm{KClO}_{4}$ was dissolved by covering the beaker with a Teflon cover and heating the solution to near boiling. Potassium perchlorate was crystallized by removing the cover and allowing the solution to concentrate to about $35 \mathrm{ml}$. The solution was allowed to cool to room temperature and then to about $5{ }^{\circ} \mathrm{C}$ by placing it in the refrigerator overnight. The crystallized potassium perchlorate was recovered from the solution by filtering it through a fine porosity polyethylene filter. After the $\mathrm{KClO}_{4}$ was washed with a cold 95 percent ethanol solution, it was returned to the Teflon beaker and the crystallization process was repeated except that only $2 \mathrm{ml}$ of perchloric acid were added. The recrystallized $\mathrm{KClO}_{4}$ was again caught on the polyethylene filter and washed with cold 95 percent ethanol. The purified material was dried by passing clean air over the $\mathrm{KClO}_{4}$.

TABLE 3. Spark source-isotope dilution mass spectrographic analysis of purified natural potassium chloride

\begin{tabular}{c|c||c|c}
\hline Element & $\begin{array}{c}\text { Concentration } \\
\mu \mathrm{g} / \mathrm{g}\end{array}$ & Element & $\begin{array}{c}\text { Concentration } \\
\mu \mathrm{g} / \mathrm{g}\end{array}$ \\
\hline $\mathrm{Al}$ & 0.6 & $\mathrm{Mo}$ & 5 \\
$\mathrm{Ba}$ & 1 & $\mathrm{Na}$ & 10 \\
$\mathrm{Bi}$ & 0.3 & $\mathrm{Ni}$ & 4
\end{tabular}

TABlE 3. Spark source-isotope dilution mass spectrographic analysis of purified natural potassium chloride - Continued

\begin{tabular}{c|c||c|c}
\hline \hline Element & $\begin{array}{c}\text { Concentration } \\
\mu \mathrm{g} / \mathrm{g}\end{array}$ & Element & $\begin{array}{c}\text { Concentration } \\
\mu \mathrm{g} / \mathrm{g}\end{array}$ \\
\hline $\mathrm{Ca}$ & 1 & $\mathrm{~Pb}$ & 1 \\
$\mathrm{Cd}$ & 2 & $\mathrm{Se}$ & 6 \\
$\mathrm{Co}$ & 3 & $\mathrm{Sn}$ & 4 \\
$\mathrm{Cr}$ & 2 & $\mathrm{Sr}$ & 0.1 \\
$\mathrm{Cu}$ & 2 & $\mathrm{Te}$ & 2 \\
$\mathrm{Fe}$ & 11 & $\mathrm{Tl}$ & 0.4 \\
$\mathrm{Mg}$ & 1 & $\mathrm{Zn}$ & 0.4 \\
$\mathrm{Mn}$ & 1 & & \\
\hline
\end{tabular}

The purified $\mathrm{KClO}_{4}$ was transferred back to the Teflon beaker and dissolved in $150 \mathrm{ml}$ of hot water. This solution, while still hot, was passed through a cation exchange column containing $50 \mathrm{ml}$ of AG50X8 resin, 100-200 mesh which is a strongly acidic cation exchange resin. (The polyethylene and resin were previously cleaned with $800 \mathrm{ml}$ of $5 \mathrm{~N} \mathrm{HCl}$.) The column was washed with $100 \mathrm{ml}$ of water to completely remove perchloric acid from the column and the potassium was eluted with $200 \mathrm{ml}$ of $5 \mathrm{~N} \mathrm{HCl}$. The eluate containing the potassium was caught in the original Teflon beaker and evaporated to dryness.

The residue of potassium chloride was transferred to a $15 \mathrm{~cm} \times 1 \mathrm{~cm} \times 1 \mathrm{~cm}$ platinum boat. The boat was transferred to a quartz tube furnace and the boat and contents were ignited under oxygen at $550{ }^{\circ} \mathrm{C}$ for $2 \mathrm{~h}$ to oxidize the organic residue from the column. (To avoid any possibility of cross isotopic contamination, the ignitions were performed in new separate quartz tubes which had never been exposed to potassium.)

Calculations based on the starting weights of ${ }^{39} \mathrm{KCl}$ and ${ }^{41} \mathrm{KCl}$ and the weights of the corresponding purified salts showed about 95 percent of the potassium was recovered in each case.

The acids and water used during these purifications were produced at NBS by subboiling distillation [57] and have been shown to be extremely low in trace cation contamination. Apparatus such as beakers, columns, and filters were vigorously cleaned with high-purity acid.

\subsection{Preparation and Analysis of the Separated Isotope Solutions}

The $3.7 \mathrm{~g}$ of purified ${ }^{39} \mathrm{KCl}$ were dissolved in about $50 \mathrm{ml}$ of $(1+49) \mathrm{HCl}$, transferred to a tared $250 \mathrm{ml}$ Teflon-FEP screw cap bottle and diluted to about 190 $\mathrm{ml}$ with $(1+49) \mathrm{HCl}$. The $3.3 \mathrm{~g}$ of purified ${ }^{41} \mathrm{KCl}$ were dissolved in about $50 \mathrm{ml}$ of $(1+49) \mathrm{HCl}$, transferred to a tared $500 \mathrm{ml}$ Teflon-FEP screw cap bottle and diluted to about $350 \mathrm{ml}$ with $(1+49) \mathrm{HCl}$. The bottles and contents were weighed to $\pm 0.2 \mathrm{mg}$ and the preliminary potassium concentration were calculated. The solution of ${ }^{39} \mathrm{KCl}$ was designated "K39" and the solution of ${ }^{41} \mathrm{KCl}$ was designated "K41".

Samples of the "K39" and "K41" solutions were analyzed for impurity elements by isotope dilutionspark source mass spectrometry [57]. Samples equivalent to about $100 \mathrm{mg}$ of $\mathrm{K}$ were spiked with 
$10^{-7} \mathrm{~g}$ of ${ }^{109} \mathrm{Ag},{ }^{137} \mathrm{Ba},{ }^{44} \mathrm{Ca},{ }^{111} \mathrm{Cd},{ }^{53} \mathrm{Cr},{ }^{65} \mathrm{Cu},{ }^{54} \mathrm{Fe}$, ${ }^{113} \mathrm{In},{ }^{26} \mathrm{Mg},{ }^{62} \mathrm{Ni},{ }^{206} \mathrm{~Pb},{ }^{82} \mathrm{Se},{ }^{117} \mathrm{Sn},{ }^{86} \mathrm{Sr},{ }^{125} \mathrm{Te},{ }^{203} \mathrm{Tl}$, and ${ }^{67} \mathrm{Zn}$. Most of the potassium matrix was removed by crystallization of potassium perchlorate and concentration of the solution to about $0.2 \mathrm{ml}$. The liquid was removed from the crystallized $\mathrm{KClO}_{4}$ by decantations and concentrated to about $0.05 \mathrm{ml}$ by evaporation. Each solution was then evaporated to dryness on high purity gold wires and analyzed by spark-source mass spectrometry. In addition to these elements, Al, Bi, Co, Mo, and Mn were estimated by comparison to. other nuclides. In addition, $\mathrm{Rb}$ and $\mathrm{Cs}$, which are not removed by the purification procedure were determined by thermal ionization mass spectrometry by spiking with ${ }^{87} \mathrm{Rb}$, measuring the ${ }^{85} \mathrm{Rb} /{ }^{87} \mathrm{Rb}$ ratio and comparing the ${ }^{132} \mathrm{Cs}$ to ${ }^{87} \mathrm{Rb}$. The results of the analysis for impurities are shown in table 4. No element was detected at a level high enough to cause a significant error in the assay procedure, that is greater than $100 \mu \mathrm{g} / \mathrm{g}$.

TABLE 4. Impurities in potassium separated isotopes

\begin{tabular}{c|c|c}
\hline \hline Element & $\begin{array}{c}\text { "K39" } \\
\mu \mathrm{g} / \mathrm{g}^{\mathrm{a}}\end{array}$ & $\begin{array}{c}\mathrm{K} 4 \mathrm{l} " \\
\mu \mathrm{g} / \mathrm{g}^{\mathrm{a}}\end{array}$ \\
\hline $\mathrm{Al}$ " & 1.5 & 0.5 \\
$\mathrm{Ba}$ & 0.6 & .09 \\
$\mathrm{Ca}$ & .4 & .3 \\
$\mathrm{Cd}$ & .3 & .09 \\
$\mathrm{Cr}$ & .4 & .5 \\
$\mathrm{Cs}$ & .1 & .1 \\
$\mathrm{Cu}$ & .3 & .1 \\
$\mathrm{Fe}$ & .8 & 1.2 \\
$\mathrm{Mg}$ & .2 & 0.2 \\
$\mathrm{Na}$ & 1 & 1.4 \\
$\mathrm{Ni}$ & 0.1 & 0.06 \\
$\mathrm{~Pb}$ & .09 & .03 \\
$\mathrm{Rb}$ & .3 & .4 \\
$\mathrm{Sn}$ & 1 & .01 \\
$\mathrm{Sr}$ & 0.04 & .01 \\
$\mathrm{Te}$ & .06 & .05 \\
$\mathrm{Tl}$ & .1 & .05 \\
$\mathrm{Zn}$ & .5 & .09 \\
\hline
\end{tabular}

${ }^{a}$ Essentially all of the values represent upper limit values. b Compared to ${ }^{26} \mathrm{Mg}$.

\subsection{Assay of Separated Isotope Solutions}

The bottles containing the potassium separated isotope solutions were shaken to thoroughly mix the solution and the screw cap closures were replaced with prepunctured polyethylene stoppers. Four weighed portions of about $15 \mathrm{~g}$ for the "K39" solution and about $30 \mathrm{~g}$ for the "K41" solution, equivalent to about $4 \mathrm{mmol}$ of $K$, were withdrawn from each solution in the following manner. A 16-cm platinum needle was inserted through the prepunctured polyethylene stopper. A 20-ml polyethylene hypodermic syringe was attached to the Kel-F hub of the needle and the desired amount of solution was withdrawn. The syringe was then disconnected from the hub and the tip was capped with a Kel-F hub. Any static charge that might be present on the plastic syringe was dissipated by wiping it with a damp lintless towel and the syringe and contents were weighed on a semimicrobalance to $+0.02 \mathrm{mg}$. The solution was then delivered into a Teflon-FEP beaker and the syringe was again capped, wiped and weighed. The weight of the sample was determined from the weights of the syringe before and after delivery of the sample. Since about $30 \mathrm{ml}$ of the "K41" solution were required to produce a 4-mmol sample, two loadings of the $20-\mathrm{ml}$ syringe were weighed for each assay sample. Two assay samples were withdrawn from each solution before the calibration samples were withdrawn and two samples were withdrawn after the calibration samples to insure that no change in concentration occurred during this time interval (about $6 \mathrm{~h}$ ).

Each sample was then assayed as follows: Two $\mathrm{ml}$ of $(1+1) \mathrm{HClO}_{4}$ was added to the weighed portion of the separated isotope solution. The solution was heated to dissolve the precipitated potassium perchlorate, $\mathrm{KClO}_{4}$, and evaporated to constant volume at about $85{ }^{\circ} \mathrm{C}$. The temperature of the hot plate was then raised to about $110{ }^{\circ} \mathrm{C}$ to volatilize the excess perchloric acid. The beaker and contents were cooled to room temperature, $15 \mathrm{ml}$ of water were added and the solution was heated until the crystallized $\mathrm{KClO}_{4}$ dissolved. The solution was again evaporated and any excess perchloric acid was removed by heating at about $110^{\circ} \mathrm{C}$. These evaporations freed the $\mathrm{KClO}_{4}$ from chloride and occluded perchloric acid.

The recrystallized potassium perchlorate was again dissolved in $15 \mathrm{ml}$ of water by heating and the solution was evaporated until only about $1 \mathrm{ml}$ of solution remained with the crystallized $\mathrm{KClO}_{4}$. (This was estimated by weighing the beaker and contents.) After cooling to room temperature, $4 \mathrm{ml}$ of perchloric acid were added and the beaker and contents were cooled to about $5{ }^{\circ} \mathrm{C}$ in a refrigerator for $16 \mathrm{~h}$ (overnight).

The crystallized potassium perchlorate was transferred with cold $\left(5{ }^{\circ} \mathrm{C}\right) 95$ percent ethanol to a tared $15 \mathrm{ml}$ fine porosity borosilicate glass filtering crucible. As much of the salt as possible was transferred by scraping the sides of the beaker with a Teflon "policeman" and washing the salt into the crucible with cold ethanol. The filtrate and original beaker were reserved for the determination of dissolved and untransferred potassium.

The filtering crucible and contents were dried at $110{ }^{\circ} \mathrm{C}$ for $2 \mathrm{~h}$ and at $300{ }^{\circ} \mathrm{C}$ for $4 \mathrm{~h}$, cooled in a desiccator, and then transferred to the case of a microbalance and allowed to stand for several hours. The crucible and contents were then weighed to $+0.002 \mathrm{mg}$. A buoyancy correction for the glass crucible was made by averaging three empty tare crucibles. The air weight of the $\mathrm{KClO}_{4}$ was then determined and converted to vacuum weight using 2.522 for the density of ${ }^{39} \mathrm{KClO}_{4}$ and 2.557 for the density of ${ }^{41} \mathrm{KClO}_{4}$. These densities were calculated by assuming that they are proportional to the density of natural $\mathrm{KClO}_{4}$ in the same relationship as their molecular weights. For simplicity of calculations, the vacuum weight of the potassium perchlorate was converted to millimoles of potassium using the calculated atomic weight for potassium and 1973 atomic weight values for chlorine and oxygens. The formula 
TABLE 5. Assay-potassium separated isotope solutions

\begin{tabular}{|c|c|c|c|c|c|c|c|}
\hline Solution & Sample & $\begin{array}{l}\text { Weight } \\
\mathrm{KClO}_{4} \\
\stackrel{\sigma}{c}\end{array}$ & $\begin{array}{c}\mathrm{KClO}_{4} \\
\mathrm{Kmol}\end{array}$ & $\begin{array}{c}\text { Filtrate } \\
\mathrm{K} \\
\mathrm{mmol}\end{array}$ & $\begin{array}{c}\text { Total } \\
\mathrm{K} \\
\mathrm{mmol}\end{array}$ & $\begin{array}{l}\text { Weight } \\
\text { sample } \\
\dot{g}\end{array}$ & $\begin{array}{l}\text { Conc. } \\
\text { sample } \\
\text { mmol }\end{array}$ \\
\hline "K39" & $\begin{array}{l}1 \\
2 \\
3 \\
4\end{array}$ & $\begin{array}{r}0.517358 \\
.543999 \\
.531849 \\
.522707\end{array}$ & $\begin{array}{l}3.737737 \\
3.930210 \\
3.842430 \\
3.776382\end{array}$ & $\begin{array}{r}0.007600 \\
.005786 \\
.004935 \\
.003977\end{array}$ & $\begin{array}{l}3.745337 \\
3.935996 \\
3.847365 \\
3.780359\end{array}$ & $\begin{array}{r}14.52021 \\
15.25967 \\
14.91381 \\
14.65616 \\
\text { Averaqe }= \\
\text { s.d. }=\end{array}$ & $\begin{array}{r}0.257939 \\
.257934 \\
.257973 \\
.257936 \\
.257946 \\
.000018\end{array}$ \\
\hline "K4l" & $\begin{array}{l}1 \\
2 \\
3 \\
4\end{array}$ & $\begin{array}{r}0.514726 \\
.492306 \\
.487376 \\
.498044\end{array}$ & $\begin{array}{l}3.666247 \\
3.506555 \\
3.471440 \\
3.547426\end{array}$ & $\begin{array}{r}0.006539 \\
.005527 \\
.006114 \\
.005187\end{array}$ & $\begin{array}{l}3.672786 \\
3.512082 \\
3.477554 \\
3.552613\end{array}$ & $\begin{array}{r}30.03932 \\
28.72888 \\
28.44437 \\
29.05879 \\
\text { Average }= \\
\text { s.d. }=\end{array}$ & $\begin{array}{r}0.122266 \\
.122249 \\
.122258 \\
.122256 \\
.122257 \\
.000008\end{array}$ \\
\hline
\end{tabular}

weights used were 138.4148 for ${ }^{39} \mathrm{KClO}_{4}$ and 140.3959 for ${ }^{41} \mathrm{KClO}_{4}$.

The beaker in which the precipitation was performed was thoroughly washed with hot water and the washings were combined with the filtrate. The "K39" solutions were spiked with about $15 \mu \mathrm{mol}$ of ${ }^{41} \mathrm{~K}$ and the "K4l" solutions were spiked with about $15 \mu \mathrm{mol}$ of ${ }^{39} \mathrm{~K}$ for determining soluble and untransferred potassium by isotope dilution mass spectrometry. The spiked solution was mixed, $1 \mathrm{ml}$ of nitric acid was added and the solution was evaporated to constant volume at about $85{ }^{\circ} \mathrm{C}$. A few $\mathrm{ml}$ of water was added and the solution was evaporated to dryness at a higher temperature. The residue was taken up in $5 \mathrm{ml}$ of water and passed through a column containing $3 \mathrm{ml}$ of AG50X8 cation exchange resin. After washing the column with $20 \mathrm{ml}$ of $\mathrm{H}_{2} \mathrm{O}$, the potassium was eluted with $20 \mathrm{ml}$ of $5 \mathrm{~N} \mathrm{HCl}$. The eluate was evaporated to dryness and taken up in $0.3 \mathrm{ml}$ of $(1+49) \mathrm{HCl}$ and the ${ }^{39} \mathrm{~K} /{ }^{41} \mathrm{~K}$ ratio was determined by thermal ionization mass spectrometry. The potassium found by isotope dilution was added to the potassium from the gravimetric determination to yield the total potassium in the sample. The concentration was then calculated by dividing this value by the weight of the sample. Table 5 shows the results of these determinations.

This method of determining the concentration of potassium solutions was previously tested on solutions containing known amounts of potassium. Six solutions were prepared from SRM 999 which is certified to contain $52.435 \pm 0.004$ percent potassium by weight in the approximate concentration of the separated isotope solution. Four samples containing from 3.5 to $5.0 \mathrm{mmol}$ of potassium were withdrawn from each solution and the potassium concentrations were determined as described.

Comparison of the calculated and measured concentrations of the six solutions showed that: (a) the concentration of potassium determined by this method agreed to within 0.01 percent of the calculated potassium concentration, (b) systematic errors were negligible, and (c) the analyses were of equal precision.

From these analyses and the analyses of the separated isotope solutions, the standard deviation of an individual measurement of the concentration of a potassium solution was computed to be $0.000017 \mathrm{mmol} / \mathrm{g}$ (24 degrees of freedom). The uncertainty of the concentration at the 95 percent confidence level is computed to be $0.000018 \mathrm{mmol} / \mathrm{g}$ for the "K39" solution and $0.000008 \mathrm{mmol} / \mathrm{g}$ for the "K4l" solution.

\subsection{Isotopic Analysis of Separated Isotopes}

Two aliquots of each separated isotope were utilized for mass spectrometric analysis. One aliquot was withdrawn from each separated isotope solution before blending of the first calibration mix and the other immediately after finishing the last calibration mix. Each of the premixing separated isotope solutions was analyzed eight times and each of the postmixing solutions was analyzed two times for a total of 10 analyses per instrument. A comparison of the observed isotopic ratios of these solutions revealed no significant contamination during preparation of the calibration mixes.

Exclusive of variable isotopic fractionation between analyses, the major sources of error in determining the isotopic composition of highly enriched separated isotopes are memory, contamination. filament background and nonlinearity of the measuring circuit. Memory effects were minimized by thorough cleaning and conditioning of the ion source for analysis of each separated isotope. The ${ }^{39} \mathrm{~K}$ background contribution of the bare degassed filaments was confirmed to be $1 \times 10^{-15} \mathrm{~A}$ by mass spectrometric analysis. A selected number of these filaments were removed from the mass spectrometer and a known quantity, either $10 \mu \mathrm{g}$ or $25 \mu \mathrm{g}$, of potassium separated isotope was immediately deposited on each sample filament. When analyzed, the effect of natural potassium was much larger than could be accounted for by a nominal $1 \times 10^{-15} \mathrm{~A}$ filament background. This "threshold effect," where a small amount of sample on the filament surface is necessary to obtain an accurate measure of filament blank, was observed when the ionizing filament was used for a single analysis or when used for as many as four different analyses with four different sets of sample filaments. The effect of filament blank on the ${ }^{39} \mathrm{~K} /{ }^{41} \mathrm{~K}$ ratios of the separated isotopes was approximately 
0.002 percent and 0.05 percent for ${ }^{39} \mathrm{~K}$ and ${ }^{41} \mathrm{~K}$, respectively.

Bias due to $\mathrm{RC}$ response of the measuring circuit was minimized by delaying a minimum of $30 \mathrm{~s}$ to allow the system to stabilize after magnetically switching peak tops. Continuous monitoring of ${ }^{39} \mathrm{~K}$ on the faraday cage produced a condition in which the ${ }^{39} \mathrm{~K} /{ }^{41} \mathrm{~K}$ ratio decreased more than could be accounted for by the isotopic fractionation associated with the heating pattern. Removing the ${ }^{39} \mathrm{~K}$ ion current from the collector for less than $5 \mathrm{~min}$ produced a recovery to the initially observed ${ }^{39} \mathrm{~K} /{ }^{41} \mathrm{~K}$ ratio. This change was in the same direction and, in most cases, of the same magnitude as that obtained from isotopic fractionation. The maximum change observed, including isotopic fractionation, for a normal analysis in which ${ }^{39} \mathrm{~K}$ was continuously focused on the faraday cage was 0.5 percent. A most likely cause of this condition, secondary electrons, was investigated with negative results. The number and position of collector suppressor magnets, increased suppressor voltage on collector plates and two different thoroughly cleaned collectors on two different mass spectrometers did not have any significant effect. A nonlinear response of a component of the measuring circuit because of continuous and prolonged exposure to $10^{-10} \mathrm{~A}$ ion currents was also a likely cause but could not be proven. Although this effect was not detected for any other sample, precautions were taken to avoid prolonged or continuous monitoring of $10^{-10} \mathrm{~A}$ ion currents, to limit ratio measurements to less than $10 \mathrm{~min}$, and to defocus the ions from the collector for $5 \mathrm{~min}$ between each measurement cycle within an analysis.

Corrected isotopic compositions of the separated isotopes are reported in table 6 . The uncertainties are limits of error which are larger than the calculated 95 percent confidence limits and which include additional components for nonlinearity and the effects of a natural potassium filament blank.

TABLE 6. Isotopic composition of separated potassium isotopes

\begin{tabular}{ll|r}
\hline \hline Separated isotope & $\begin{array}{c}\text { Isotopic composition } \\
\text { (atom percent) }\end{array}$ \\
\hline "K39" & ${ }^{39} \mathrm{~K}$ & $99.9765 \pm 0.0004$ \\
& ${ }^{40} \mathrm{~K}$ & $0.0014 \pm .0001$ \\
& ${ }^{41} \mathrm{~K}$ & $.0221 \pm .0004$ \\
& & \\
& & $0.8186+0.0020$ \\
& ${ }^{39} \mathrm{~K}$ & $.0004 \pm .0001$ \\
& ${ }^{40} \mathrm{~K}$ & $99.1810 \pm .0020$ \\
\hline
\end{tabular}

The uncertainties are based on minimum errors for the ratio determinations. The calculated 95 percent confidence limits are well below the minimum error statement.

\subsection{Preparation of the Calibration Samples}

Six calibration samples were prepared by mixing weighed portions of the "K39" and "K41" solutions to produce five calibration samples with ${ }^{39} \mathrm{~K} /{ }^{41} \mathrm{~K}$ ratios that approximated natural potassium and varied over a range of 4 percent. A sixth calibration sample was prepared with a ${ }^{39} \mathrm{~K} /{ }^{41} \mathrm{~K}$ ratio of 1 . The portions were withdrawn from the bottles and weighed in the manner previously described. To eliminate any possibility of change in concentration of the isotope solutions with time, the portions for the calibration samples were withdrawn from the bottles at the same time the samples for determining the potassium concentrations were withdrawn.

TABLE 7. Composition of potassium calibration samples

\begin{tabular}{c|c|c|c|c|c}
\hline \hline $\begin{array}{c}\text { Sample } \\
\text { No. }\end{array}$ & $\begin{array}{c}\text { Isotope } \\
\text { solution }\end{array}$ & $\begin{array}{c}\text { Weight } \\
\text { solution } \\
\mathrm{g}\end{array}$ & $\begin{array}{c}{ }^{39} \mathrm{~K} \\
\mathrm{mmol}\end{array}$ & $\begin{array}{c}{ }^{41} \mathrm{~K} \\
\mathrm{mmol}\end{array}$ & $\begin{array}{c}{ }^{39} \mathrm{~K} /{ }^{41} \mathrm{~K} \\
\text { ratio }\end{array}$ \\
\hline 1 & "K39"” & 6.74034 & 1.738235 & 0.0003842 & 14.13808 \\
& "K41" & 1.01137 & 0.001012 & .1226344 & \\
2 & "K39"” & 7.49182 & 1.932031 & .0004271 & 13.91228 \\
& "K41" & 1.14244 & 0.001143 & .1385274 & \\
3 & "K39", & 7.07292 & 1.824002 & .0004032 & 13.94269 \\
& "K41" & 1.07620 & 0.001077 & .1304954 & \\
& "K39", & 7.19697 & 1.855994 & .0004103 & 13.67965 \\
& "K41" & 1.11621 & 0.001117 & .1353469 & \\
& "K39", & 7.25150 & 1.870055 & .0004134 & 13.55556 \\
6 & "K41" & 1.13500 & 0.001136 & .1376252 & \\
& "K39", & 2.45747 & .6337456 & .0001401 & 0.989239 \\
\hline
\end{tabular}

Table 7 shows the calculated isotopic composition of the calibration samples. The isotopic ratio of each calibration sample was calculated from the isotopic analysis of the separated isotopes and the mmol of potassium from each separated isotope solution.

Each calibration sample was thoroughly mixed by stirring and evaporated to dryness on a hot plate. The calibration samples were taken up with $(1+49) \mathrm{HCl}$ so that $1 \mathrm{ml}$ of solution contained $2.5 \mathrm{mg}$ of $\mathrm{K}$.

\subsection{Isotopic Analysis of the Calibration Mixes and the Reference Standard}

Two complete and independent sets of analyses of the calibration mixes and the reference standard were made, one on MS \#1 by Operator I and the other on MS \#5 by Operator II. Each set consisted of 18 analyses of the calibration mixes and 18 analyses of the standard. Exclusive of the equal atom calibration mix which was analyzed on a clean source, a simple alternating pattern of standard and calibration mix was maintained until three analyses per calibration mix were obtained. Four solutions of the high purity potassium chloride standard were prepared and stored in specially cleaned Teflon bottles. Three of these samples were representative of different positions of the bulk material and the fourth was a composite of the first three. The composite sample was processed through an ion exchange column to duplicate the treatment of the separated isotopes during the purification procedure.

Operator I utilized the digital system to determine 
TABLE 8. Determination of correction factors

\begin{tabular}{|c|c|c|c|c|c|c|}
\hline \multirow{2}{*}{$\begin{array}{l}\text { Calibration } \\
\text { sample No. }\end{array}$} & \multicolumn{3}{|c|}{$-\ldots--{ }^{39} \mathrm{~K} /{ }^{41} \mathrm{~K}$ Ratio ----} & \multicolumn{3}{|c|}{---- Correction factor ${ }^{\mathrm{a}}----$} \\
\hline & $\begin{array}{c}\text { Operator I } \\
\text { (digital) }\end{array}$ & $\begin{array}{l}\text { Operator II } \\
\text { (digital) }\end{array}$ & $\begin{array}{c}\text { Operator II } \\
\text { (recorder) }\end{array}$ & $\begin{array}{l}\text { Operator I } \\
\text { (digital) }\end{array}$ & $\begin{array}{l}\text { Operator II } \\
\text { (digital) }\end{array}$ & $\begin{array}{c}\text { Operator II } \\
\text { (recorder) }\end{array}$ \\
\hline $\begin{array}{l}1 \\
2 \\
3 \\
4 \\
5 \\
6\end{array}$ & $\begin{array}{c}14.2879 \\
14.0525 \\
14.0871 \\
13.8221 \\
13.6940 \\
0.999965\end{array}$ & $\begin{array}{c}14.2723 \\
14.0432 \\
14.0766 \\
13.8088 \\
13.6838 \\
0.998973\end{array}$ & $\begin{array}{c}14.2709 \\
14.0378 \\
14.0749 \\
13.8024 \\
13.6797 \\
0.998859\end{array}$ & $\begin{array}{r}0.989590 \\
.990097 \\
.989825 \\
.989769 \\
.989966 \\
.989391\end{array}$ & $\begin{array}{r}0.990583 \\
.990666 \\
.990475 \\
.990636 \\
.990617 \\
.990250\end{array}$ & $\begin{array}{r}0.990684 \\
.991050 \\
.990598 \\
.991098 \\
.990917 \\
.990367\end{array}$ \\
\hline \multicolumn{4}{|c|}{ Mean value of correction factors $=$} & b) 0.989849 & " 0.990595 & b 0.990869 \\
\hline
\end{tabular}

a These correction factors are calculated using the individually determined compositions of the separated isotopes to compute the isotopic ratio of each calibration sample.

b Values of calibration sample No. 6 were not used in calculating the averages, but were included in the computation of the uncertainty in the ratio determination.

TABLE 9. Observed isotopic ratios of reference standard

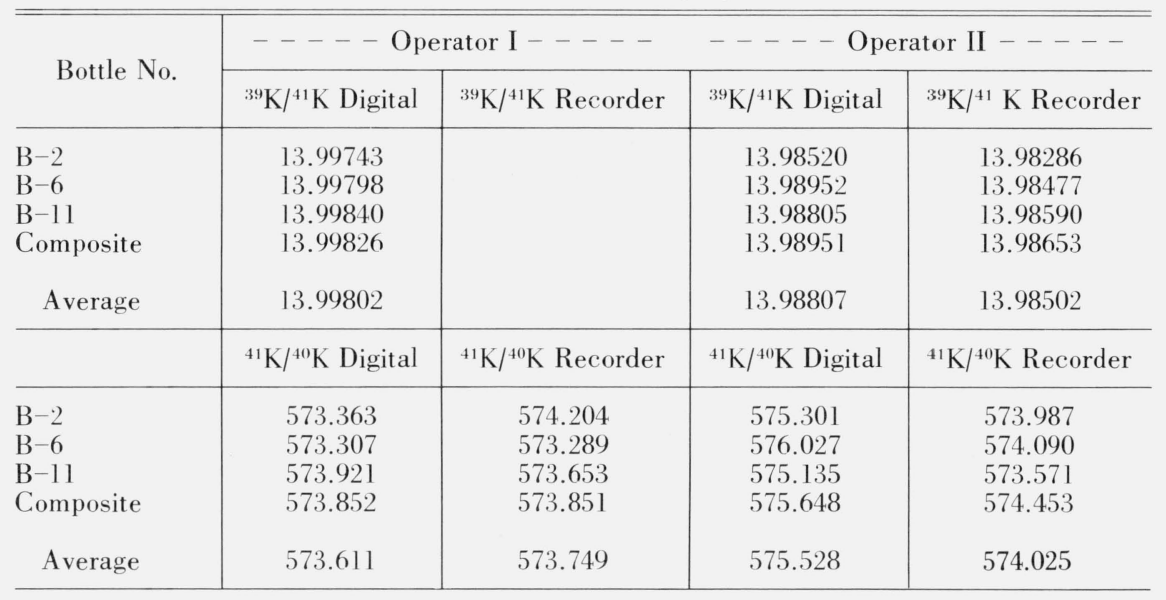

Note. - The value for each bottle is the average of five analyses.

the potassium isotopic ratios of all samples and also simultaneously recorded the data by expanded scale recorder. Of the strip chart recorder data by Operator $\mathrm{I}$, only the ${ }^{41} \mathrm{~K} /{ }^{40} \mathrm{~K}$ ratio was calculated with the intent of providing a rigorous evaluation of the linearity of the digital system. Operator II utilized the digital and expanded scale recorder in a simultaneous mode of operation to measure the isotopic ratios of all samples. Two sets of measurement by Operator II, the set of digital measurements by Operator $\mathrm{I}$, and the ${ }^{41} \mathrm{~K} /{ }^{40} \mathrm{~K}$ recorder measurements by Operator I were submitted to a statistician for analysis.

\section{Results and Discussion}

Table 8 summarizes the analysis of the calibration mixes and the calculation of correction factors. Calibration mixes one through five formed the point calibration for determining the correction factors. Analysis of equal atom mix (No.6) yielded correction factors slightly different from the averages on both instruments. This calibration mix was excluded in calculating the average correction factors but was included in determining the uncertainty in the ratio measurement.

The average values for the observed isotopic ratios of four subsamples of the reference standard are given in table 9. The agreement between subsamples indicates that the Teflon sample containers were adequately cleaned or that any impurities leached from the containers did not affect the isotopic analysis. Organic contributions from the ion exchange column purification were also too small to significantly affect the isotopic ratios. The ${ }^{41} \mathrm{~K} /{ }^{40} \mathrm{~K}$ ratio as determined by Operator II on the digital system is biased high with respect to the recorder data on the same instrument. This bias is due to a slight amount of ${ }^{39} \mathrm{~K}$ tail at the ${ }^{40} \mathrm{~K}$ mass position on the $15 \mathrm{~cm}$ instrument. The digital system takes the linear average of two points on opposite sides of the ${ }^{40} \mathrm{~K}$ peak to determine the baseline, but the tail contribution is nonlinear. This type correction is more accurately determined from the recorder spectra. The precision of the ${ }^{39} \mathrm{~K} /{ }^{41} \mathrm{~K}$ ratio measurements are approximately the same for both operators using either digital or expanded scale re- 
TABLE 10. Determination of corrected isotopic ratios

\begin{tabular}{|c|c|c|c|c|c|c|}
\hline & \multicolumn{3}{|c|}{$--------{ }^{39} \mathrm{~K} /{ }^{41} \mathrm{~K}-------$} & \multicolumn{3}{|c|}{$-\ldots-\ldots--{ }^{41} \mathrm{~K} /{ }^{40} \mathrm{~K}-\ldots-\ldots$} \\
\hline & $\begin{array}{l}\text { Observed } \\
{ }^{39} \mathrm{~K} /{ }^{41} \mathrm{~K}\end{array}$ & $\begin{array}{l}\text { Correction } \\
\text { factor }\end{array}$ & $\begin{array}{c}\text { Corrected } \\
{ }^{39} \mathrm{~K} /{ }^{+1} \mathrm{~K}\end{array}$ & $\begin{array}{c}\text { Observed } \\
{ }^{41} \mathrm{~K} /{ }^{40} \mathrm{~K}\end{array}$ & $\begin{array}{l}\text { Correction } \\
\text { factor }\end{array}$ & $\begin{array}{l}\text { Corrected } \\
{ }^{41} \mathrm{~K} /{ }^{40} \mathrm{~K}\end{array}$ \\
\hline $\begin{array}{l}\text { Digital I } \\
\text { Digital II s.d. }= \\
\text { Recorder II s.d. }= \\
\text { s.d. }=\end{array}$ & $\begin{array}{r}13.99802 \\
0.00022 \\
13.98807 \\
0.00102 \\
13.98502 \\
0.00081\end{array}$ & $\begin{array}{l}0.989849 \\
.000114 \\
.990595 \\
.000070 \\
.990869 \\
.000114 \\
\text { Mean }=\end{array}$ & $\begin{array}{l}13.85593 \\
0.00141 \text { ( } 8 \text { d.f. }) \\
13.85651 \\
0.00195 \text { ( } 8 \text { d.f. }) \\
13.85732 \\
0.00161 \text { ( } 8 \text { d.f.) } \\
13.85662 \pm{ }^{\mathrm{a}} 0.00627\end{array}$ & $\begin{array}{r}573.611 \\
0.160 \\
575.528 \\
0.198 \\
574.025 \\
0.182\end{array}$ & $\begin{array}{l}1.005128 \\
0.000051 \\
1.004747 \\
0.000035 \\
1.004608 \\
0.000057 \\
\text { Mean }=\end{array}$ & $\begin{array}{l}576.552 \\
0.163 \text { (8 d.f.) } \\
578.260 \\
0.199 \text { (8 d.f.) } \\
576.670 \\
0.163 \text { (8 d.f.) } \\
576.6 \pm 2.0\end{array}$ \\
\hline \multicolumn{7}{|c|}{ 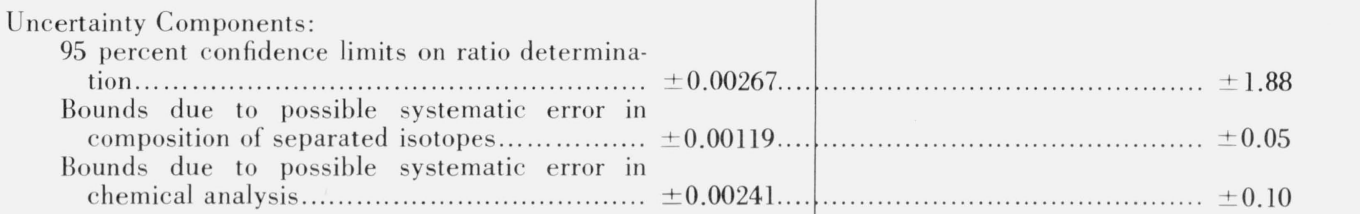 } \\
\hline
\end{tabular}

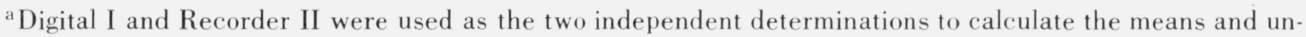
certainty component due to ratio determination.

corder measurements. The two complete sets of measurements by Operator II do not satisfy the criteria for two independent determinations. Satisfaction of this criteria requires each set of analyses to be different in all respects from sample loading through the ratio measurement. Therefore, the digital measurements of Operator I and the recorder measurement of Operator II were used as two independent determinations from which the absolute isotopic ratios, the isotopic compositions, and the atomic weight were calculated. The absolute isotopic ratios are summarized in table 10 .

The calculation of the atomic weight of the reference standard is summarized in table 11. Each uncertainty component is at least as large as the 95 percent con- fidence limit. For the ${ }^{40} \mathrm{~K} /{ }^{41} \mathrm{~K}$ ratio measurement of the standard and the isotopic ratios of the separated isotopes, the statistically calculated 95 percent confidence limits are smaller than the limiting error of the instrument. For this condition an uncertainty component larger than the calculated 95 percent confidence limit. but equivalent to the limiting error of instrument for the analytical conditions of the measurement, is used. The overall limit of error is the sum of the uncertainty components due to the isotopic composition of the separated isotopes, the chemical assay and mixing of the separated isotopes, and the mass spectrometric ratio measurement.

An extensive survey of terrestrial potassium by

TABLE 11. Summary calculations of the atomic weight of potassium in Standard Reference Material 985

\begin{tabular}{|c|c|c|c|c|}
\hline \multirow[b]{2}{*}{ Value } & \multicolumn{4}{|c|}{--------- Uncertainty Components ----------} \\
\hline & $\begin{array}{l}\text { Overall limit } \\
\text { of error }\end{array}$ & $\begin{array}{c}\text { Mass } \\
\text { spectrometric } \\
\text { analytical error }\end{array}$ & $\begin{array}{c}\text { Possible } \\
\text { systematic error } \\
\text { in composition } \\
\text { of separated } \\
\text { isotopes }\end{array}$ & $\begin{array}{c}\text { Possible } \\
\text { systematic error } \\
\text { in chemical } \\
\text { analysis }\end{array}$ \\
\hline Atomic weight $=39.098304$ & \pm 0.000058 & \pm 0.000025 & \pm 0.000011 & \pm 0.000022 \\
\hline $\begin{array}{l}\text { Nuclidic masses } \\
\qquad \begin{array}{l}\left({ }^{12} \mathrm{C}=12\right) \\
{ }^{39} \mathrm{~K}=38.9637089 \\
{ }^{40} \mathrm{~K}=39.9640001 \\
{ }^{41} \mathrm{~K}=40.9618270\end{array}\end{array}$ & $\begin{array}{l} \pm 0.0000008 \\
\pm 0.0000008 \\
\pm 0.0000011\end{array}$ & & & \\
\hline $\begin{array}{l}\text { Atomic percent } \\
{ }^{39} \mathrm{~K}=93.25811 \\
{ }^{40} \mathrm{~K}=0.011672 \\
{ }^{41} \mathrm{~K}=6.73022\end{array}$ & $\begin{array}{l} \pm 0.00292 \\
\pm 0.000041 \\
\pm 0.00292\end{array}$ & $\begin{array}{l} \pm 0.00130 \\
\pm 0.000038 \\
\pm 0.00130\end{array}$ & $\begin{array}{l} \pm 0.00053 \\
0.000001 \\
\pm 0.00053\end{array}$ & $\begin{array}{l} \pm 0.00109 \\
0.000002 \\
\pm 0.00109\end{array}$ \\
\hline $\begin{array}{l}\text { Isotopic ratios } \\
\qquad{ }^{39} \mathrm{~K} /{ }^{41} \mathrm{~K}=13.85662 \\
{ }^{40} \mathrm{~K} /{ }^{11} \mathrm{~K}=0.0017343\end{array}$ & $\begin{array}{l} \pm 0.00627 \\
\pm 0.0000061\end{array}$ & $\begin{aligned} & 0.00267 \\
\pm & 0.00000564\end{aligned}$ & $\begin{array}{l} \pm 0.00119 \\
\pm 0.00000015\end{array}$ & $\begin{array}{l} \pm 0.00241 \\
\pm 0.0000003\end{array}$ \\
\hline
\end{tabular}

a The overall limit of error is the sum of the 95 percent confidence limits and the terms covering effects of known sources of possible systematic error. 
Garner et al. [56] found no major isotopic abundance variations among approximately 70 mineral samples of different geological origins and geographic locations. Particular attention was given to include samples which might be expected to show isotopic variations or which had been previously reported to show significant isotopic variations. The average value of the minerals is biased approximately 0.03 percent higher than the ${ }^{39} \mathrm{~K} /{ }^{41} \mathrm{~K}$ of the reference standard, SRM 985. This difference is attributed to an altered fractionation pattern rather than to real differences in isotopic abundance between the minerals and reference standard. The alteration in fractionation pattern of the minerals is produced by the relative small amounts of organic and/or inorganic impurities which are not removed by the chemical separation and purification procedure.

Based on this survey, the atomic weight of terrestrial potassium is calculated to be $39.09830 \pm 0.00019$. The

\section{References}

[1] Shields, W. R., Garner, E. L., and Dibeler, V. H., J. Res. Nat. Bur. Stand. (U.S.) 66A (Phys. and Chem.) 1-3 (Jan.-Feb. 1962).

[2] Shields, W. R., Murphy, T. J., Garner, E. L., and Dibeler, V. H., J. Am. Chem. Soc. 84, 1519-1522 (1962).

[3] Shields, W. R., Murphy, T. J., and Garner, E. L., J. Res. Nat. Bur. Stand. (U.S.) 68A (Phys. and Chem.) 589-592 (Nov.Dec. 1964).

[4] Catanzaro, E. J., Murphy, T. J., Garner, E. L., and Shields, W. R., J. Res. Nat. Bur. Stand. (U.S.) 68A (Phys. and Chem.) 593-599 (Nov.-Dec. 1964).

[5] Shields, W. R., Murphy, T. J., Catanzaro, E. J., and Garner, E. L., J. Res. Nat. Bur. Stand. (U.S.) 70A (Phys. and Chem.) 193-197 (March-April 1966).

[6] Catanzaro, E. J., Murphy, T. J., Garner, E. L., and Shields, W. R., J. Res. Nat. Bur. Stand. (U.S.) 70A (Phys. and Chem.) 453-458 (Nov.-Dec. 1966).

[7] Catanzaro, E. J., Murphy, T. J., Shields, W. R., and Garner, E. L., J. Res. Nat. Bur. Stand. (U.S.) 72A (Phys. and Chem.) 261-267 (May-June 1968).

[8] Catanzaro, E. J., Champion, C. E., Garner, E. L., Marinenko, G., Sappenfield, K. M., and Shields, W. R., Nat. Bur. Stand. (U.S.), Spec. Publ. 260-17, 70 pages (Feb. 1969).

[9] Catanzaro, E. J., Murphy, T. J., Garner, E. L., and Shields, W. R., J. Res. Nat. Bur. Stand. (U.S.) 73A (Phys. and Chem.) 511-516 (Sept.-Oct. 1969).

[10] Gramlich. J. W., Murphy, T. J., Garner, E. L., and Shields, W. R., J. Res. Nat. Bur. Stand. (U.S.) 77A (Phys. and Chem.) 691-698 (Nov.-Dec. 1973).

[11] Barnes, I. L., Moore, L. J., Machlan, L. A., Murphy, T. J., and Shields, W. R., Absolute Isotopic Abundance Ratios and the Atomic Weight of a Reference Sample of Silicon, J. Res. Nat. Bur. Stand. (U.S.) 79A (Phys. and Chem.) No. 6. (Nov.Dec. 1975).

[12] Wapstra, A. H., and Gove, N. B., Nuclear Data Tables 9, 265-301 (1971).

[13] Cameron, A. E., Anal. Chem. 36, 23A-35A (1963).

[14] Brewer, A. K., J. Amer. Chem. Soc. 58, 365-370 (1936).

[15] Harms, G., Blanc, G., Espagno, L., and Blanc, D., Comptes Rendus 255, 3203-3204 (1962).

[16] Letolle, R., Comptes Rendus 254, 2205-2206 (1962).

[17] Letolle, R., Comptes Rendus 25 7, 3996-3998 (1963).

[18] Schreiner, G. D. L., and Verbeek, A. A., Proc. Roy. Soc. A285, 423-429 (1964).

[19] Lebadev, V. I., Prokofyev, L. M., Kirillov, A. S., Tarasov, A. V., Geokhimiya 10, 1255-1257 (1966). error limits include an additional component of \pm 0.000136 to cover uncertainties in the terrestrial mineral survey data resulting from possible natural isotopic variations and bias introduced by the chemical purification procedure. The reported isotopic variations of lunar potassium $[51,58]$ were treated as a special case and are not covered by the error limits for terrestrial potassium.

We are indebted to: Hsien $\mathrm{H}$. Ku for statistical analysis; W. R. Shields, former Section Chief, for his advice and efforts in initiating the project; W. A. Bowman, III, for maintenance support; Carrie A. Garfink for filament fabrication and assistance in reduction of strip chart recorder data; Joy J. Shoemaker and Josephine Ledford for skillful manuscript preparation.

[20] Verbeek, A. A., and Schreiner, 'G. D. L., Geochim. Cosmochim. Acta 31, 2125-2133 (1967).

[21] Schreiner, G. D. L., and Welke, H. J. H. F. D., Geochim. Cosmochim. Acta 35, 719-726 (1971).

[22] Cook, K. L., Phys. Rev. 64, 278-293 (1943).

[23] Kendall. B. R. F., Nature 186, 255-256 (1963).

[24] Nier, A. O., Phys. Rev. 77, 789-793 (1950).

[25] Reuterswärd, C., Arkiv Fysik 1 1, 1-54 (1956).

[26] Wichers, E., J. Am. Chem. Soc. 74, 2447-2450 (1952).

[27] Richards, T. W., and Staehler, J. Am. Chem. Soc. 29, 623-639 (1907).

[28] Richards, T. W., and Müeller, E., J. Am. Chem. Soc. 29, 639-656 (1907).

[29] Hönigschmid, O., and Gaubeau, J., Z. Anorg. Allgem. Chem. 163, 93-164 (1927).

[30] Hönigschmid, O., and Gaubeau, J., Z. Anorg. Allgem. Chem. 177, 102-108 (1928).

[31] Baxter, G. P., and MacNevin, W. M., J. Am. Chem. Soc. 55, 3185-3190 (1933).

[32] Hönigschmid, O., and Sachtleben, R., Z. Anorg. Allegem. Chem. 213, 365-376 (1933).

[33] Johnson, C. R., J. Phys. Chem. 39, 781-789 (1935).

[34] Baxter, G. P., and Harrington, C. D., J. Am. Chem. Soc. 62. 1836- 1837 (1940).

[35] McAlpine, R. K., and Bird, E. J., J. Am. Chem. Soc. 63, 2960-2965 (1941).

[36] Marinenko, G., Talanta 16, 1339-1340 (1969).

[37] Bates, R. G., and Wichers, E., J. Res. Nat. Bur. Stand. (U.S.) 59, 9-17 (July 1957).

[38] Brewer, A. K., and Kueck, P. D., Phys. Rev. 46, 894-897 (1934).

[39] Nier, A. O., Phys. Rev. 48, 283-284 (1935).

[40] Manley, J. H., Phys. Rev. 49, 921-924 (1936).

[41] Bondy, H., and Vanicek. V.. Z. Physik 101, 186-192 (1936).

[42] Paul, W., Z. Physik 124, 244-257 (1948).

[43] White, J. R., and Cameron, A. E., Phys. Rev. 74, 991-1000 (1948).

[44] Hibbs, R. F., and Redmond, J. W., Y-290, AECI-24 (1949).

[45] Reuterswärd, C., Ark. Fysik 4, 203-205 (1952).

[46] White, F. A., Collins, T. H., and Rourke, F. M., Phys. Rev. 101 , 1786-1791 (1956).

[47] Omura, I., and Morito, N., J. Phys. Soc. Japan 13, 659 (1958).

[48] Stauffer, H., and Honda, M., J. Geophys. Res. 67, 3503-3512 (1962).

[49] Shukolyukov, Yu. A., Tolstikhin, I. N., and Varshavskaya, E. S., Geokhimiya 4, 373-375 (1964).

[50] Schreiner, G. D. L., and Verbeek, A. A., Proc. Roy. Soc. A285, $423-429$ (1965)

[51] Barnes, I. L., Garner, E. L., Gramlich. J. W., Machlan, L. A., Moody, J. R., Moore, L. J., Murphy. T. J., and Shields, W. R., 
Proceedings of the Fourth Lunar Science Conference, Geochim. Cosmochim. Acta Suppl. 4, 2, 1197-1207 (1973).

[52] Shields, W. R., (Ed.), Nat. Bur. Stand. (U.S.) Tech. Note 426, 53 pages (Sept. 1967).

[53] Shields, W. R., (Ed.), Nat. Bur. Stand. (U.S.) Tech. Note 277. 99 pages (July 1966).

[54] Garner, E. L., Machlan. L. A., and Shields, W. R., Nat. Bur. Stand. (U.S.) Special Publication 260-27, 150 pages (April 1971).

[55] Garner, E. L., Machlan, L. A., Gramlich, J. W., Moore, L. A., Murphy, T. J., and Barnes, I. L., 7th IMR Research Symp., Gaithersburg, MD, Oct. 7-11, 1974. NBS Spec. Publ. 422,
U.S. Government Printing Office, Washington, D.C. 20402 (In press).

[56] Garner, E. L., Goldich, S. S., Gramlich, J. W., Machlan, L. A., and Murphy, T. J., Absolute Isotopic Composition of Terrestrial Potassium (In preparation).

[57] Kuehner, E. C., Alvarez, R., Paulsen, P. J., and Murphy, T. J., Anal. Chem. 44, 2050-2056 (1972).

[58] Garner, E. L., Machlan, L. A., and Barnes, I. L., Proceedings of the Sixth Lunar Science Conference (In press).

(Paper 79A6-869) 